\title{
POCZUCIE PODMIOTOWOŚCI I AKTYWNOŚĆ ORGANIZACYJNA MIESZKAŃCÓW ŁODZI
}

\section{WPROWADZENIE}

Współcześnie coraz więcej uwagi poświęca się refleksji nad znaczeniem kategorii podmiotowości w analizach przemian społecznych, ekonomicznych i politycznych. W myśl głównych wartości demokracji zyskuje na popularności postulat pozostawiania inicjatyw społecznych i politycznych w rękach obywateli Jak pisze K. Wielecki, aktywność podmiotu powinna przejawiać się w dążeniu do wybierania takich ,form zaspokajania własnych potrzeb oraz sposobu ich zaspokajania, które uwzględniają interes, w tym dążenie do podmiotowości innych ludzi" ${ }^{1}$.

Korzyści z podmiotowości jest bowiem wiele. Po pierwsze, podmiotowość to cecha, która chroni nas przed uleganiem manipulacji, zwiększa autodeterminację i pobudza do podejmowania różnego rodzaju działań. Po drugie, poczucie podmiotowości jest niewątpliwie niezbędnym warunkiem partycypacji, czyli udziału obywateli w zarządzaniu sprawami społeczności, której są człon$\mathrm{kami}^{2}$. I po trzecie, podmiotowość to przekonanie, że nie jest się przedmiotem, wokół którego wszystko się dzieje, ale podmiotem, od którego wiele zależy.

Innymi słowy, poczucie podmiotowości ma szczególne znaczenie w dobie doceniania walorów demokracji oraz dążenia do pełnego i świadomego uczestnictwa w budowaniu społeczeństwa obywatelskiego, nie tylko europejskiego, narodowego, ale przede wszystkim regionalnego, na poziomie społeczności lokalnej. Krótko mówiąc, poczucie sprawstwa zwiększa szansę na aktywne funkcjonowanie w świecie, tym samym przyczyniając się do budowania wspomnianego społeczeństwa obywatelskiego, które coraz częściej traktuje się jako remedium na rozwiązywanie problemów społecznych.

Niestety, znamienną cechą Polski jest niski poziom aktywności społecznej we wszystkich analizowanych wymiarach. Dość nisko kształtuje się zarówno aktywność obywatelska, jak i prospołeczna czy kooperacyjna. Jak wynika z badań, zdecydowana większość naszego społeczeństwa nie wykazuje zainteresowania sprawami wykraczającymi poza życie prywatne, nie podejmuje

${ }^{1}$ K. Wielecki, Podmiotowość społeczna i jej makrostrukturalne uwarunkowania, w: P. Buczkowski, R. Cichocki (red.), Podmiotowość: możliwość, rzeczywistość, konieczność, Wydawnictwo Ośrodka Analiz Społecznych ZMW, Poznań 1989.

2 J. Hausner (red.), Komunikacja i partycypacja społeczna. Poradnik, Wydawnictwo Małopolskiej Szkoły Administracji Publicznej Akademii Ekonomicznej, Kraków 1999. 
działań obywatelskich w celu współtworzenia świata wokół siebie ani nie jest chętna do angażowania się w rozwiązywanie problemów społecznych ${ }^{3}$. Niechęć do wspólnego działania oraz pewność skuteczniejszej realizacji obranego celu $\mathrm{w}$ pojedynkę stają się niejako opisem aktywności w naszym kraju. Polacy określani są jako ci, którzy „nie umieją, bo nie działają, a nie działaja, bo nie umieja"

Warto zobaczyć, jak na tym tle kształtują się podmiotowość i aktywność społeczna mieszkańców Łodzi. Celem artykułu jest zatem próba odpowiedzi na pytanie, jaki jest poziom podmiotowości i aktywności łodzian, oraz zbadanie wpływu podmiotowości na jeden z wymiarów aktywności, czyli zaangażowanie w działalność mniej lub bardziej sformalizowanych organizacji pozarządowych.

Podstawę empiryczną niniejszego artykułu stanowi materiał badawczy zgromadzony w ramach grantu promotorskiego „Kapitał społeczny, postawy przedsiębiorczości i jakości życia mieszkańców Łodzi” w 2010 r. Badaniem objęto 497 dorosłych mieszkańców Łodzi. Próba ma charakter reprezentatywny.

\section{UJĘCIE TEORETYCZNE PODMIOTOWOŚCI}

Mimo iż pojęcie podmiotowości jest tak popularne i powszechnie używane, trudno znaleźć jedną jego definicję, która pozwalałaby w miarę precyzyjnie oddzielać zjawiska, jakie pojęcie to obejmuje, od innych. Niezwykle trudno odróżnić podmiotowość od wolności, emancypacji, tożsamości.

Niewątpliwie jednak intuicje związane z pojęciem podmiotowości prowadza nas w kierunku takich zagadnień, jak: rola człowieka i jego aktywności w procesach społecznych, problem wolności we wszystkich sferach życia społecznego ${ }^{5}$. Bez watpienia zagadnienia te znajduja odzwierciedlenie $\mathrm{w}$ refleksji filozoficznej.

„W antropologii filozoficznej pojęcie podmiotowości oznacza przeciwieństwo reifikacji, uprzedmiotowienia jednostki i podjęte zostaje przez te kierunki, które akcentuja wolność, kreatywność, dezalienację człowieka. W epistemologii oznacza odrzucenie mechanistycznej teorii odbicia i podkreślenie czynnej roli poznającego rozumu. W historiozofii oznacza sprzeciw wobec fatalizmu i determinizmu, a także finalizmu czy prowidencjalizmu, na rzecz perspektywy aktywistycznej i posybilistycznej”6. A zatem, każdy z tych trzech wymiarów myślenia filozoficznego akcentuje rolę człowieka, jego relację do otaczającej rzeczywistości, a nade wszystko możliwość wpływu na ową rzeczywistość.

\footnotetext{
${ }^{3}$ CBOS, Spoteczeństwo obywatelskie 1998-2004, Warszawa 2004; CBOS, Poczucie wptywu na sprawy publiczne, Warszawa 2008; CBOS, Aktywność Polaków w organizacjach obywatelskich w latach 1998-2010, Warszawa 2010.

${ }^{4}$ A. Sułek, Doświadczenie i kompetencje obywatelskie Polaków, w: J. Czapiński, T. Panek (red.), Diagnoza spoteczna 2009. Warunki i jakość życia Polaków, Warszawa 2009.

${ }^{5}$ K. Gorlach, Z. Seręga, Socjologiczna koncepcja podmiotowości - zarys problemów badawczych, w: P. Buczkowski, R. Cichocki (red.), Podmiotowość: możliwość, rzeczywistość, konieczność, „Studia Młodzież i Wieś”, Wydawnictwo Ośrodka Analiz Społecznych ZMW, Poznań 1989.

${ }^{6}$ P. Sztompka, Socjologiczna teoria podmiotowości, w: P. Buczkowski, R. Cichocki, op. cit.
} 
Odmienny nieco sens pojęcie podmiotowości uzyskuje w psychologii. K. Korzeniowski zainteresowanie podmiotowością wiąże przede wszystkim z rozwojem różnych wersji psychologii humanistycznej. Mówi on o trzech momentach, które sa istotne dla rozpatrywania ludzkiej podmiotowości. $\mathrm{Na}$ pierwszy składa się działalność podmiotowa, czyli realne oddziaływanie i dokonywanie zmian w świecie. Moment drugi podkreśla świadomość podejmowanych działań, a za pomoca trzeciego K. Korzeniowski utwierdza nas w przekonaniu, że podmiotowość to także psychologiczna odrębność i autonomia ${ }^{7}$.

W naukach politycznych podmiotowość utożsamiana jest z samorządnością, autonomią jednostek i grup społecznych. Zgodnie $\mathrm{z}$ założeniem, że na podmiotowość składają się świadomość i aktywność, o byciu podmiotem decyduje samouświadomienie, świadomość samego siebie, czyli samowiedza, która generuje skłonność do działania świadomego ${ }^{8}$. A zatem $\mathrm{w}$ tym ujęciu, tak jak i w wypadku refleksji psychologicznej, mamy do czynienia $\mathrm{z}$ aktywnym nastawieniem do otaczającej rzeczywistości.

Podobnie rzecz się ma $\mathrm{w}$ wypadku socjologicznego znaczenia terminu „,podmiotowość”. Zadaniem P. Sztompki centralną kategoria jest tutaj działanie człowieka, będące wyrazem jego aktywnej postawy wobec świata, o która współcześnie tak bardzo się zabiega. Przez podmiotowość rozumie on przede wszystkim ,,aktywny wpływ działań ludzkich na kształt struktury społecznej”. Działanie człowieka charakteryzuje w tym wypadku refleksyjność, planowanie, konstruowanie otaczającej rzeczywistości. Innymi słowy, jest to zdolność społeczeństwa do samodzielnego przekształcania się.

M. Wieruszewska pisze, że „poczucie podmiotowości i przeświadczenie o wpływie na różne sfery życia zgodne $\mathrm{z}$ własnymi lub uznawanymi standardami, wspomagają się wzajemnie i minimalizują rozmaite doświadczenia uzależnienie, bezradności, podporządkowania"10. Jak się okazuje, świadomość, że jest się podmiotem działania, ma decydujące znaczenie $\mathrm{w}$ podejmowaniu inicjatyw na rzecz otaczającej nas rzeczywistości. Przekonanie o samostanowieniu generuje zaangażowanie i lepsza jakość podejmowanych działań. „Jak pokazały dotychczasowe doświadczenia, narzucanie gotowych wzorców rozwoju może dać jedynie efekty krótkotrwałe, a nawet odwrotne do zamierzonych i niszczące dla społeczności lokalnej" ${ }^{11}$. A zatem, aby społeczeństwo obywatelskie mogło się prawidłowo rozwijać, potrzeba udziału obywateli w zarządzaniu sprawami społeczności, potrzeba aktywności społecznej. Zaangażowanie w sprawy „małych ojczyzn” zdaje się warunkiem koniecznym.

\footnotetext{
${ }^{7} \mathrm{~K}$. Korzeniowski, Uwarunkowaniach zmienności $i$ stabilności $w$ czasie poczucia podmiotowości - alienacji politycznej, w: P. Buczkowski, R. Cichocki, op. cit.

${ }^{8}$ M. Karwat, Podmiotowość polityczna: humanistyczna interpretacja polityki $w$ marksizmie, WN PWN, Warszawa 1980, s. 274.

${ }^{9}$ P. Sztompka, op. cit., s. 5.

${ }^{10}$ M. Wieruszewska (red.), Samoorganizacja $w$ spotecznościach wiejskich, Instytut Rozwoju Wsi i Rolnictwa PAN, Warszawa 2002, s. 42.

${ }^{11}$ L. Juroszek, Partycypacja lokalna $w$ gminie Isdebna i możliwość jej wykorzystania $w$ zrównoważonym rozwoju gminy, w: H. Podedworna, P. Ruszkowski (red.), Społeczne aspekty zrównoważonego rozwoju wsi w Polsce. Partycypacja lokalna i kapitat spoteczny, Scholar, Warszawa 2008, s. 54.
} 


\section{POZIOM PODMIOTOWOŚCI MIESZKAŃCÓW ŁODZI}

Uwzględniając dominujące akcenty w różnych stanowiskach teoretycznych, proponuję rozpatrywać podmiotowość: po pierwsze - jako autodeterminizm, czyli zdolność stanowienia o sobie; po drugie - jako poczucie sprawstwa i po trzecie -jako aktywność jednostki w procesach społecznych. Wśród wskaźników tak rozumianej podmiotowości wymienia się między innymi dążenie do wolności, która stanowi podstawowy i pierwszy warunek wszelkiego działania, ocenę możliwości zmiany własnych warunków życia w efekcie podjętych przez siebie działań i aktywny udział w tworzeniu rzeczywistości społecznej.

Empirycznymi wyznacznikami wyżej wymienionych komponentów podmiotowości są w niniejszym opracowaniu odpowiednio: pytanie o prawo do samodzielnego decydowania w sprawach moralnych bez kierowania się opiniami Kościoła i innych autorytetów, opinia o wpływie przeciętnego obywatela na to, co robią lokalne władze, i w końcu odpowiedź na pytanie dotyczące podejmowania działań na rzecz społeczności lokalnej.

Pierwszy z komponentów tak rozumianej podmiotowości określony został, jako autodeterminizm. Jak pisze I. Krzemiński: ,,społeczeństwo obywatelskie jest oparte na idei, że każdy członek społeczności, bez względu na to, kim jest, jaką ważną rolę odgrywa $\mathrm{w}$ danej wspólnocie, ma prawo decydować o swoim losie i zabierać głos w sprawach, które go dotyczą" ${ }^{12}$. Możliwość samodecydowania o sobie stanowi istotę poczucia podmiotowości. Często jednak ludzie pozostaja pod wpływem autorytetów, które ograniczają możliwość samodzielnego decydowania o sobie.

Jak wynika z deklaracji (tabela 1) większości mieszkańców Łodzi (38,7\%), jednostka zdecydowanie powinna mieć prawo do samodzielnego decydowania w sprawach moralnych bez konieczności kierowania się opiniami Kościoła i innych autorytetów. Po zgrupowaniu poszczególnych kategorii okazuje się, że $\mathrm{z}$ opinią tą zgadza się $86,6 \%$ badanych. Odmiennego zdania jest $13,4 \%$ zapytanych osób.

Powyższe dane pozwalaja zatem przyjąć, że w całej populacji badanych dominują ludzie, którzy chca samodzielnie stanowić o swoim życiu. Zdaniem M. Kofty: „każdy z nas obdarzony jest zdolnością do subiektywnego doświadczenia i przeżywania świata, samoświadomością i zdolnością do autorefleksji, wolnością wyboru, zdolnością podejmowania decyzji i celowego kierowania swoim postępowaniem, zdolnością do odróżniania dobra i zła, a więc etycznego wartościowania własnych i cudzych postępków" ${ }^{13}$.

Zgodnie z teorią podmiotowości jednostka powinna mieć także poczucie sprawstwa, czyli przekonanie o wpływie na otaczająca rzeczywistość. Empirycznym wyznacznikiem tego komponentu stało się w tym wypadku pytanie o opinie o wpływie przeciętnego obywatela na to, co robia lokalne władze. $\mathrm{Z}$ przeprowadzonych analiz (tabela 2) wynika, że zdecydowana większość łodzian zgadza się ze stwierdzeniem, że przeciętny obywatel nie ma wpływu na

\footnotetext{
${ }^{12}$ I. Krzemiński, Co się dzieje między ludźmi, Instytut Socjologii UW, Warszawa 1992, s. 34.

${ }^{13}$ M. Kofta, Psychologia aktywności, zaangażowanie, sprawstwo, bezradność, Nakom, Poznań 1993, s. 98.
} 


\section{Tabela 1}

\section{Autodeterminizm}

\begin{tabular}{|l|c|c|}
\hline $\begin{array}{c}\text { W jakim stopniu się Pan zgadza ze stwierdzeniem, } \\
\text { że jednostka powinna mieć prawo do samodzielnego } \\
\text { decydowania w sprawach moralnych } \\
\text { bez konieczności kierowania się opiniami } \\
\text { na przykład przedstawicieli Kościoła } \\
\text { i innych autorytetów? }\end{array}$ & Częstotliwość & Odsetek \\
\hline Zdecydowanie się zgadzam. & 191 & 38,7 \\
\hline W większym stopniu się zgadzam, niż nie zgadzam. & 136 & 27,5 \\
\hline Raczej się zgadzam. & 101 & 20,4 \\
\hline W połowie się zgadzam, w połowie się nie zgadzam. & 39 & 7,9 \\
\hline Raczej się nie zgadzam. & 17 & 3,4 \\
\hline W większym stopniu się nie zgadzam, niż zgadzam. & 2 & 0,4 \\
\hline Zdecydowanie się nie zgadzam. & 8 & 1,6 \\
\hline Ogółem & 494 & 100,0 \\
\hline
\end{tabular}

Źródło: opracowanie własne.

\section{Tabela 2}

\section{Poczucie sprawstwa}

\begin{tabular}{|l|c|c|}
\hline $\begin{array}{c}\text { W jakim stopniu zgadza się P. ze stwierdzeniem } \\
\text { „Ludzie tacy jak ja nie maja wpływu na to, } \\
\text { co robią lokalne władze” }\end{array}$ & Częstotliwość & Odsetek \\
\hline Zdecydowanie się zgadzam. & 168 & 33,9 \\
\hline W większym stopniu się zgadzam, niż nie zgadzam. & 113 & 22,8 \\
\hline Raczej się zgadzam. & 107 & 21,6 \\
\hline W połowie się zgadzam, w połowie nie zgadzam. & 50 & 10,1 \\
\hline Raczej się nie zgadzam. & 35 & 7,1 \\
\hline W większym stopniu się nie zgadzam, niż zgadzam. & 13 & 2,6 \\
\hline Zdecydowanie się nie zgadzam. & 9 & 1,8 \\
\hline Ogółem & 497 & 100,0 \\
\hline
\end{tabular}

Źródło: opracowanie własne.

to, co robia lokalne władze. Wszyscy respondenci, którzy w mniejszym lub większym stopniu podzielają tę opinię, stanowią niespełna $80 \%$ badanych.

Jak wynika $\mathrm{z}$ danych zaprezentowanych $\mathrm{w}$ tabeli 2, pewnego rodzaju poczucie sprawstwa posiada zaledwie 11,5\% łodzian. Jest to dość niski wynik w porównaniu z badaniami ogólnopolskimi z 2007 r. Wówczas ponad $40 \%$ 
Polaków zadeklarowało poczucie wpływu na sprawy lokalne ${ }^{14}$. W wypadku łodzian ten aspekt podmiotowości pozostawia wiele do życzenia i nie napawa optymizmem, tym bardziej że - jak wynika z wielu badań - poczucie sprawstwa koreluje $\mathrm{z}$ aktywnym uczestniczeniem $\mathrm{w}$ życiu społecznym ${ }^{15}$.

Krótko mówiąc, poczucie wpływu na otaczającą rzeczywistość jest ważnym elementem podmiotowości. W znaczący sposób podkreślają to psychologowie, twierdząc, że o byciu podmiotem przesądza miejsce, jakie jednostka zajmuje w otaczającym świecie, i wpływ, jaki jej własna działalność na ten świat wywiera" ${ }^{16}$.

Wyznacznikiem podmiotowości jest także aktywny udział $\mathrm{w}$ tworzeniu rzeczywistości społecznej. Do zbadania tego wymiaru wybrano pytanie dotyczące wykonywania działań na rzecz Łodzi. Rozkład odpowiedzi prezentuje rysunek 1 .

\section{Rysunek 1}

Czy w ciagu ostatnich 4 lat zdarzyło się Panu(i) dobrowolnie i bezpłatnie pracować na rzecz Łodzi?

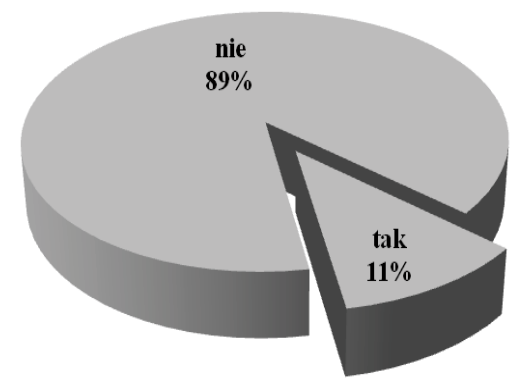

Źródło: opracowanie własne.

Z deklaracji ankietowanych wynika, że zdecydowana większość łodzian (89\%) nie wykonywała żadnych prac na rzecz swojego miasta. W odniesieniu do uzyskanych danych nasuwa się tylko jeden wniosek: mieszkańcy Łodzi biernie uczestniczą $\mathrm{w}$ tworzeniu rzeczywistości społecznej. Ten komponent podmiotowości, podobnie jak poczucie sprawstwa, kształtuje się na bardzo niskim poziomie. Z trzech analizowanych wymiarów podmiotowości najlepiej wypada „,autodeterminizm”, czyli przekonanie o prawie do samostanowienia.

Jak się jednak okazuje, między trzema wyróżnionymi wymiarami zachodzi korelacja istotna statystycznie, większość z nich jest ze sobą powiązana. Oznacza to, że występowanie jednego z nich ma wpływ na inne: osoby, które

${ }^{14}$ CBOS, Czy zwykty cztowiek ma poczucie wptywu na sprawy publiczne, Warszawa 2007.

${ }^{15}$ CBOS, Aktywność Polaków w organizacjach obywatelskich w latach 1998-2010, Warszawa 2010.

16 A. Korzeniowski, op. cit., s. 42. 
maja poczucie wpływu na otaczająca rzeczywistość - po pierwsze - częściej wykonywały jakieś bezpłatne prace na rzecz poprawy warunków zamieszkania na terenie swojej miejscowości $(\mathrm{V} 0,182, \mathrm{p} 0,000)$ i po drugie - charakteryzowały się większym poczuciem prawa do samostanowienia (V 0,175 p 0,000).

Tabela 3

Korelacja pomiędzy wymiarami podmiotowości

\begin{tabular}{|l|c|c|c|}
\hline & Autodeterminizm & $\begin{array}{c}\text { Poczucie } \\
\text { sprawstwa }\end{array}$ & $\begin{array}{c}\text { Aktywność } \\
\text { społeczna }\end{array}$ \\
\hline Autodeterminizm & $\mathrm{X}$ & Brak zależności & $\mathrm{p} 0,036$ VC 0,116 \\
\hline Poczucie sprawstwa & $\mathrm{p} 0,000 \mathrm{VC} 0,175$ & $\mathrm{X}$ & $\mathrm{p} 0,028$ VC 0,127 \\
\hline Aktywność społeczna & $\mathrm{p} 0,036 \mathrm{VC} 0,116$ & $\mathrm{p} 0,000$ VC 0,191 & $\mathrm{X}$ \\
\hline
\end{tabular}

Źródło: opracowanie własne.

Istotna statystycznie zależność wystąpiła także pomiędzy wymiarem „,aktywność społeczna” a ,poczucie sprawstwa”. Okazuje się, że osoby, którym zdarzyło się wykonywać bezpłatnie prace na rzecz Łodzi, mają znacznie większe przekonanie o wpływie na to, co robią lokalne władze, niż te, które w tym wymiarze przejawiały bierność.

Mając świadomość istnienia korelacji pomiędzy badanymi wymiarami podmiotowości, zbudowano wskaźnik syntetyczny podmiotowości mieszkańców Łodzi. Wskaźnik ten składa się z trzech itemów: autodeterminizmu, poczucia sprawstwa i aktywności społecznej. Z przeprowadzonej analizy wynika, że średni poziom podmiotowości łodzian kształtuje się na poziomie 1,8 , przy odchyleniu standardowym 0,57 . Okazuje się, że większość badanych $(67,8)$ posiada podmiotowość składającą się z dwóch wymiarów. Jedna czwarta badanych charakteryzuje się podmiotowością obejmującą zaledwie jeden wymiar. Wszystkie trzy wymiary typowe są natomiast dla niespełna $5 \%$ badanych. Biorąc pod uwagę fakt, że wymiary te są ze sobą w jakiś sposób powiązane, to tak niski wynik ,,pełnej” podmiotowości rodzić może pewne obawy. Bez wątpienia jednak jest to potwierdzenie tezy, że podmiotowość Polaków nie została do końca ukształtowana. Nadal wiele osób nie potrafi uznać siebie za podmiot, który ma zdolność wpływania na otoczenie. Niestety, to tak zwane dyspozycyjne poczucie podmiotowości ${ }^{17}$ stanowi istotna przeszkodą w budowaniu społeczeństwa obywatelskiego.

${ }^{17}$ W. Daniecki, Poczucie podmiotowości i jego uwarunkowania organizacyjne, w: K. Korzeniowski et al. (red.), Podmiotowość jednostki $w$ koncepcjach psychologicznych i organizacyjnych, Ossolineum, Wrocław 1983. 


\section{AKTYWNOŚĆ ORGANIZACYJNA MIESZKAŃCÓW ŁODZI}

Aktywność społeczna stanowi bardzo ważny element społeczeństwa obywatelskiego. Jednym $\mathrm{z}$ wymiarów tej aktywności jest zaangażowanie w rożnego rodzaju organizacje pozarządowe, które stanowią odrębny typ organizacji społecznych klasyfikowanych jako „trzeci sektor”, obok sektora prywatnego i publicznego.

Organizacje te stanowia formę instytucji społecznych nastawionych na zaspakajanie zróżnicowanych potrzeb mieszkańców i pełnią wiele istotnych funkcji. Służą między innymi umacnianiu społecznego ładu i przyczyniają się do poprawy warunków i jakości życia. Nie dziwi zatem fakt, że zainteresowanie funkcjonowaniem organizacji pozarządowych towarzyszy od wielu już lat zarówno teoretykom, jak i praktykom życia społecznego, tym bardziej że poziom zaangażowania $\mathrm{w}$ te organizacje plasuje się $\mathrm{w}$ Polsce na relatywnie niskim poziomie.

Z danych CBOS-u wynika, że $\mathrm{w}$ tym wymiarze możliwość społecznego działania wykorzystuje niewielu Polaków ${ }^{18}$. W 2008 r. wskaźnik aktywności $\mathrm{w}$ organizacjach osiaggnął zaledwie $11 \%$ i w porównaniu z krajami europejskimi był on dość niski. Co więcej, według danych pochodzących z pierwszej edycji Europejskiego Sondażu Społecznego dla lat 2002-2003 Polska zajęła ostatnie miejsce, jeśli chodzi o członkowstwo w organizacjach społecznych. Poziom przynależności wyniósł $19,1 \%$, co w porównaniu z najwyższym wskaźnikiem 83,8\% (Holandia), oznacza wartość bardzo niską ${ }^{19}$.

Jednakże przeprowadzane $\mathrm{w}$ ostatnich latach badania na próbie ogólnopolskiej ${ }^{20}$ pokazuja, że zainteresowanie przynależnością do organizacji obywatelskich wzrasta. W ubiegłym roku odnotowano na przykład najwyższy wskaźnik aktywności w organizacjach obywatelskich od momentu rozpoczęcia procesu monitorowania, czyli od $1998 \mathrm{r} .{ }^{21}$ Niestety wskaźniki te nadal nie sa zadowalające. Polskie społeczeństwo wykazuje stosunkowo słabe zainteresowanie praca społeczną w organizacjach obywatelskich. Problem ten, jak się okazuje, dotyczy także mieszkańców Łodzi.

Przeprowadzone badania ujawniły, że aktywność organizacyjna łodzian kształtuje się na dość niskim poziomie. Jak wynika $\mathrm{z}$ danych zamieszczonych w tabeli 4, najwięcej badanych - prawie $83 \%$ - nie należy do żadnej z 26 wymienionych organizacji. Warto wspomnieć, że nieznacznie wyższy wskaźnik bierności organizacyjnej odnotowano w wśród mieszkańców Gdańska, tam wyniósł on $88 \%{ }^{22}$.

Wśród dominującej liczby osób nieaktywnych organizacyjnie znalazło się niespełna $12 \%$ tych, którzy przynależą przynajmniej do jednej organizacji,

${ }^{18}$ CBOS 2010, op. cit.

${ }^{19}$ H. Domański, Społeczeństwo europejskie. Stratyfikacja $i$ systemy wartości, Scholar, Warszawa 2009 .

${ }^{20}$ J. Czapiński, T. Panek (red.), Diagnoza społeczna 2007. Warunki i jakość życia Polaków, Vizja Press \& IT, Warszawa 2007.

${ }^{21}$ CBOS 2010, op. cit.

${ }^{22}$ Raport z badań dotyczących oceny działalności władz miasta oraz aktywności społecznej mieszkańców Gdańska, przeprowadzony w 2008 r. przez Uniwersytet Gdański. 
Tabela 4

Poziom zaangażowania w organizacjach pozarządowych

\begin{tabular}{|c|c|c|}
\hline $\begin{array}{c}\text { Liczba organizacji pozarzadowych, } \\
\text { do których przynależy }\end{array}$ & Częstotliwość & Odsetek \\
\hline $\mathbf{0}$ & 412 & 82,9 \\
\hline $\mathbf{1}$ & 58 & 11,7 \\
\hline $\mathbf{2}$ & 15 & 3,0 \\
\hline $\mathbf{3}$ & 7 & 1,4 \\
\hline $\mathbf{4}$ & 1 & 0,2 \\
\hline $\mathbf{5}$ & 3 & 0,6 \\
\hline $\mathbf{6}$ & 1 & 0,2 \\
\hline Ogółem & 497 & 100,0 \\
\hline
\end{tabular}

Źródło: opracowanie własne.

i 5,4\% badanych, którzy działają w więcej niż jednej z 25 analizowanych organizacji. Warto zaznaczyć, że porównywalne dane co do przynależności do organizacji zarejestrowano w Mieście Podlaskim (11,5\%) i Mieście Warmińskim $(13,9 \%)^{23}$. A zatem przywołane dane pozwalają spojrzeć na niską aktywność w organizacjach obywatelskich łodzian z większą pobłażliwością.

Nie zmienia to jednak faktu, że ogólny poziom zaangażowania mieszkańców Łodzi w organizacje pozarządowe jest relatywnie niski. Srednia w tym względzie mierzona na skali 0-6 wyniosła 0,26, przy odchyleniu standardowym 1,74. Bardzo dobrze ilustruje to skonstruowana skala ,,przynależność organizacyjna", obejmująca 26 itemów wchodzących w skład analizowanego wymiaru aktywności. Informacje w wartościach skonstruowanej skali prezentuje w sposób graficzny poniższy histogram z krzywą normalną (rysunek 2).

Statystyki opisowe badanej zmiennej wskazują, że w badanym zbiorze występuje jedna wartość modalna, która wynosi 0. Oznacza to, że dominującym typem zachowania mieszkańców Łodzi jest brak zaangażowania w organizacje obywatelskie.

Wartość współczynnika skośności dla analizowanej zmiennej wynosi 3,952 możemy więc powiedzieć, że rozkład zmiennej ,,przynależność organizacyjna” jest skrajnie asymetryczny (asymetria dodatnia), co oznacza, że dla większości łodzian wartość tego wskaźnika jest niższa niż średnia $(0,26)$.

Natomiast struktura przynależności do poszczególnych organizacji jest poniekąd zbieżna z tym, co uzyskano w badaniach ogólnopolskich ${ }^{24}$. Łodzianie najczęściej angażują się w działalność związaną ze szkolnictwem i oświatą,

${ }^{23}$ M. Theiss, Krewni - Znajomi - Obywatele. Kapitat spoteczny a lokalna polityka spoteczna, Wydawnictwo Adam Marszałek, Toruń 2007.

${ }^{24}$ CBOS, op. cit. 


\section{Rysunek 2}

Histogram prezentujący rozkład zmiennej syntetycznej „,przynależność organizacyjna”

\section{Histogram}

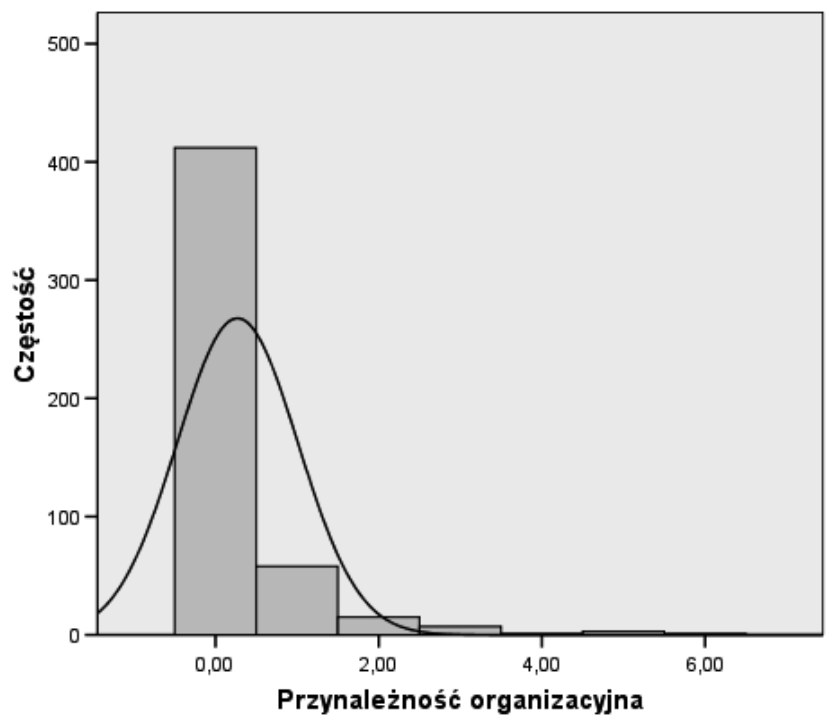

Średnia $=0,2696$

OdchStd. $=0,74036$ $\mathrm{N}=497$

związkami zawodowymi, stowarzyszeniami i klubami sportowymi. Poświęcają swój wolny czas również związkom działkowiczów, hodowców, wędkarzy, myśliwych, organizacjom charytatywnym, organizacjom działającym na rzecz ochrony środowiska naturalnego oraz organizacjom i ruchom kościelnym, wspólnotom parafialnym i organizacjom młodzieżowym.

Zaznaczyć należy, że udział badanych w wyżej wymienionych dziedzinach aktywności nie przekroczył 4\%. Przynależność do 16 innych organizacji jest mniejsza niż 1\%. Dwie ostatnie (organizacje, stowarzyszenia turystyczne i komitety starające się o załatwienie jakiejś konkretnej sprawy, grupy protestu) nie zostały wybrane w ogóle.

\section{POCZUCIE PODMIOTOWOŚCI JAKO WYZNACZNIK PRZYNALEŻNOŚCI ORGANIZACYJNEJ}

Poziom aktywności społecznej zależy od wielu czynników. Wśród nich wymienia się typ kultury, rodzaj systemu, a także cechy jednostkowe. Zdaniem P. Sztompki poziom podmiotowości zależy na przykład od kultury zaufania. Jej przeciwieństwo, tak zwana ,kultura nieufności, prowadząc do demobilizacji, pasywizmu, ostrożności, oportunizmu, dystansów społecznych, atomizacji, alie- 
nacji - obniża potencjał podmiotowy społeczeństwa, jego zdolność do twórczego, innowacyjnego samoprzekształcania się"25.

Aktywność społeczna, w tym właśnie przynależność organizacyjna, zależeć może także od systemu społeczno-politycznego. Bez wątpienia zmiany systemowe i legislacyjne, jakie dokonały się w Polsce po 1989 r., miały istotne znaczenie dla powstawania organizacji pozarządowych ${ }^{26}$. I w końcu, analizowany rodzaj aktywności warunkowany jest także cechami jednostkowymi, wśród których wymienia się cechy położenia społecznego, a także poczucie podmiotowości ${ }^{27}$.

W niniejszym artykule analizie poddany zostanie jedynie czynnik jednostkowy, a dokładniej: wpływ poczucia podmiotowości mieszkańców Łodzi na ich aktywność organizacyjną. Z wielu badań wynika bowiem, że poczucie wpływu na sprawy publiczne koreluje $\mathrm{z}$ aktywnym uczestniczeniem $\mathrm{w}$ życiu społecznym $^{28}$. Innymi słowy: ,,poczucie podmiotowości i przeświadczenie o wpływie na różne sfery życia zgodne z własnymi lub uznawanymi standardami, wspomagają się wzajemnie i minimalizują rozmaite doświadczenia uzależnienia, bezradności, podporządkowania" 29 .

W celu zbadania wpływu podmiotowości na przynależność organizacyjna mieszkańców Łodzi przeprowadzono jednoczynnikową analizę wariancji. W wyniku dokonanych analiz uzyskano istotny statystycznie efekt dwóch komponentów podmiotowości: poczucia sprawstwa, $\mathrm{F}(2,492)=4,563 ; \mathrm{p}=0,000$ oraz aktywności, $\mathrm{F}(1,494)=62,827 ; \mathrm{p}=0,000$. Uzyskane zależności w sposób graficzny prezentują rysunki 3 i 4, z których wynika, że istnieje statystycznie istotny związek pomiędzy przynależnością organizacyjną mieszkańców Łodzi a ich poczuciem sprawstwa i podejmowaną aktywnością. Okazuje się, że osoby, które zadeklarowały wykonywanie prac na rzecz Łodzi, angażują się w działalność organizacji obywatelskich znacznie częściej niż badani, którzy nie podjęli tego typu aktywności. Potwierdza się zatem przekonanie, że komponent ten warunkuje przynależność organizacyjną.

Pozytywnie zweryfikowany został także wpływ drugiego komponentu podmiotowości, czyli poczucie sprawstwa. Z analiz wynika, że osoby, które sa przekonane o tym, iż moga wpływać na to, co się wokół nich dzieje, statystycznie istotnie częściej udzielają się w badanych organizacjach pozarządowych.

Statystycznie nieistotną determinantą przynależności organizacyjnej okazał się trzeci z wyróżnionych komponentów podmiotowości (autodeterminizm). $\mathrm{Z}$ analizy średnich wynika jednak, że osoby które charakteryzują się poczuciem prawa do samostanowienia, częściej poświęcają swój czas na pracę w organizacjach pozarządowych niż badani, którzy takiego poczucia nie mają.

${ }^{25}$ P. Sztompka, Socjologia. Analiza społeczeństwa, Znak, Kraków 2002, s. 324.

${ }^{26}$ P. Gliński, H. Palska, Cztery wymiary spotecznej aktywności obywatelskiej, w: H. Domański, A. Rychard (red.), Elementy nowego tadu, Wydawnictwo IFiS PAN, Warszawa 1993.

${ }^{27}$ CBOS 2010, op. cit.

28 Ibidem.

${ }^{29}$ M. Wieruszewska (red.), Samoorganizacja w spotecznościach wiejskich, Instytut Rozwoju Wsi i Rolnictwa PAN, Warszawa 2002, s. 42. 


\section{Rysunek 3}

Przynależność organizacyjna a poczucie sprawstwa

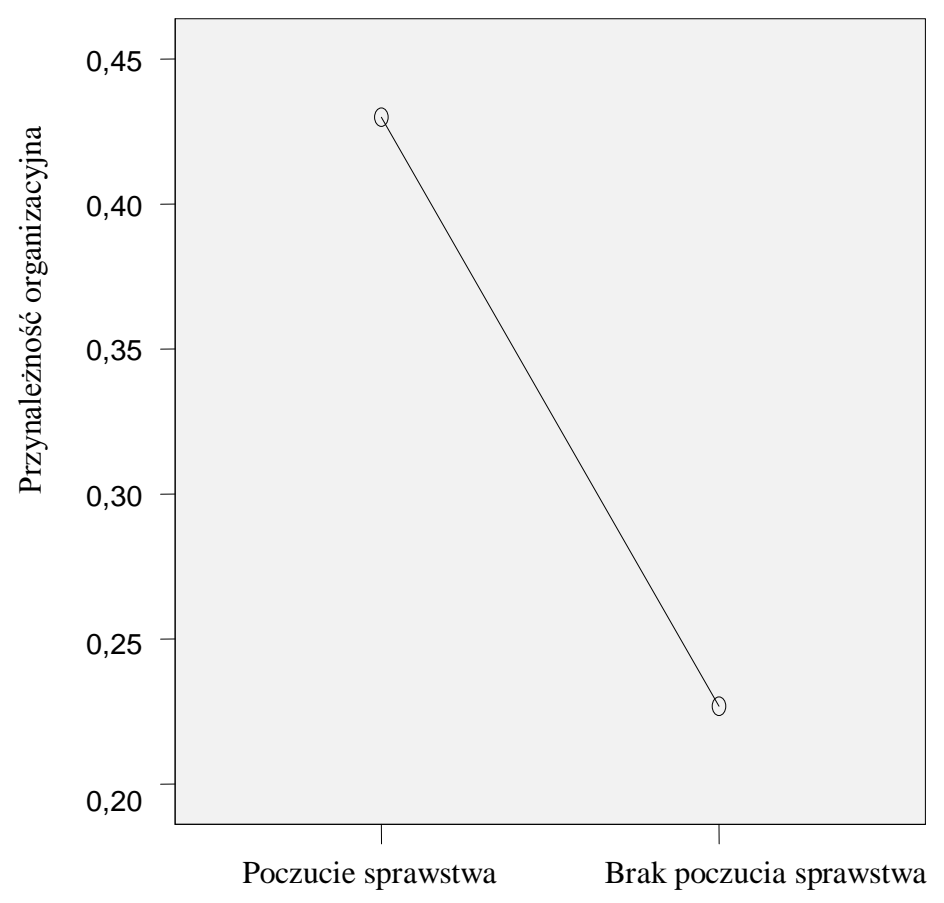

\section{Rysunek 4}

Przynależność organizacyjna a aktywność

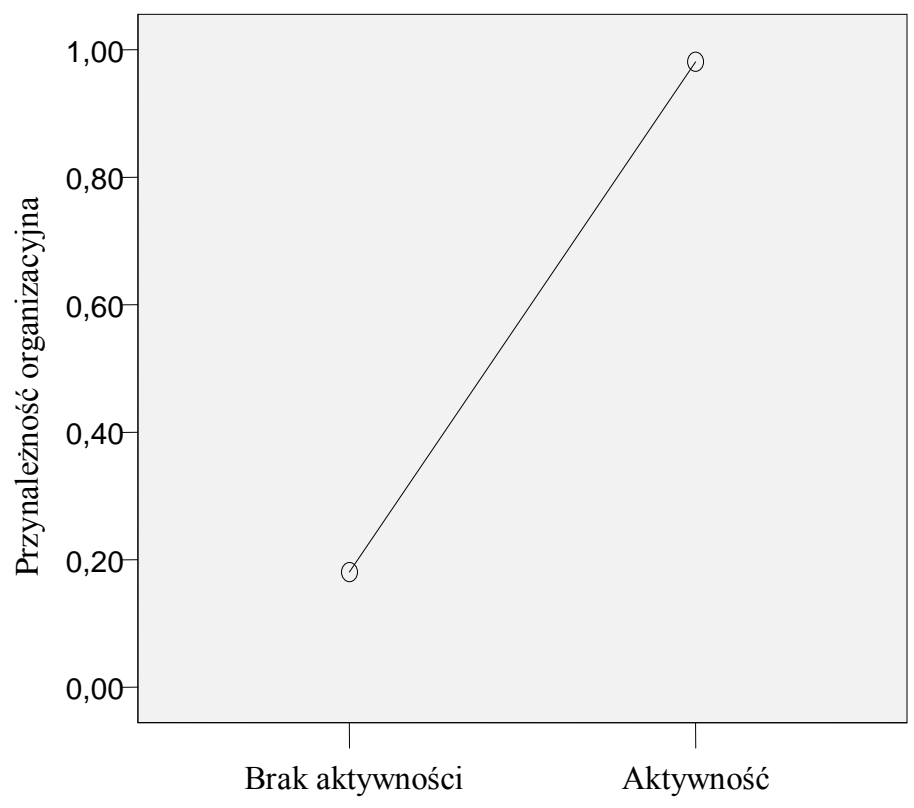


Zależność pomiędzy podmiotowością a przynależnością organizacyjną potwierdzona została także w odniesieniu do skonstruowanych skal badanych zjawisk. Dla analizowanych zmiennych obliczono współczynnik rho - Spearmana, który przyjął wartość $\mathrm{S}=0,473 ; \mathrm{p}=0,005$. Korelacja okazała się istotna. Istnieje umiarkowany, dodatni związek między obiema zmiennymi. Oznacza to, że wysokim wartościom jednej zmiennej towarzyszą wysokie wartości drugiej.

\section{PODSUMOWANIE}

Dane przedstawione $\mathrm{w}$ niniejszym opracowaniu upoważniają, w moim przekonaniu, do sformułowania następujących wniosków co do podmiotowości i przynależności organizacyjnej mieszkańców Łodzi.

Wśród badanej zbiorowości dominuje niskie poczucie podmiotowości, a przekonanie, że każdy obywatel nie musi być przedmiotem, wokół którego wszystko się dzieje, ale może być podmiotem, od którego wiele zależy, nie jest jeszcze w pełni wykształcone. Łodzianie nie potrafią, jak się okazuje, w pełni korzystać z możliwości, jakie stwarza obywatelom ustrój demokratyczny. Stanowi to, niestety, istotną przeszkodę w budowaniu społeczeństwa obywatelskiego, czyli przejmowaniu odpowiedzialności za dobro wspólne i angażowaniu się w rozwiązywanie problemów społecznych.

Przynależność organizacyjna mieszkańców Łodzi kształtuje się na bardzo niskim poziomie. Jak się okazuje, niewielu badanych wykorzystuje możliwość działania w różnego typu stowarzyszeniach, fundacjach, związkach, partiach, samorządach, klubach, komitetach. Powodów tak niskiej aktywności jest zapewne wiele, począwszy od czynników kulturowych, przez rodzaj systemu, a na czynnikach jednostkowych skończywszy. Analizując uwarunkowania przynależności organizacyjnej, wskazuje się także na poziom podmiotowości społecznej, czyli zdolność jednostki do wywierania wpływu na strukturę społeczną. Poczucie podmiotowości okazuje się niezbędnym warunkiem partycypacji, czyli udziału obywateli w zarządzaniu sprawami społeczności, której są członkami ${ }^{30}$, a konieczność zaznaczenia się jako świadomy, aktywny i odpowiedzialny podmiot jest artykułowana w coraz większym stopniu. Stąd też kreowanie podmiotowości stanowi istotne wyzwanie.

Ważne zadanie stoi zatem przed realizatorami programów aktywizacji społeczności lokalnych, którzy poprzez organizowanie i prowadzenie szkoleń, podnoszenie kwalifikacji lokalnych liderów, pracowników organizacji pozarządowych i instytucji publicznych, prowadzenie poradnictwa i konsultacji edukują społeczności lokalne wzmacniają działania lokalnych grup obywatelskich, buduja tożsamość wspólnot lokalnych, a także pomagają ludziom w tworzeniu ich własnej społeczności lokalnej. Te działania sa natomiast niczym innym, jak sposobem na przejmowanie większej kontroli nad własnym życiem, a tym samym sposobem na upodmiotowienie obywateli. Tym bardziej że

${ }^{30}$ J. Hausner (red.), Komunikacja i partycypacja społeczna. Poradnik, Wydawnictwo Małopolskiej Szkoły Administracji Publicznej Akademii Ekonomicznej, Kraków 1999. 
korzyści z zaangażowania obywatelskiego jest wiele: ,jak wskazują dotychczasowe doświadczenia - właśnie społeczeństwo obywatelskie może przeciwdziałać marginalizacji społecznej wielu Polaków i osłabieniu Państwa"31. Może także przyczynić się do wypracowania przez Polskę godnej pozycji w jednoczącej się Europie. Poza tym, ,jak pokazały dotychczasowe doświadczenia, narzucanie gotowych wzorców rozwoju może dać jedynie efekty krótkotrwałe, a nawet odwrotne od zamierzonych i niszczące dla społeczności lokalnej”32.

mgr Monika Mularska-Kucharek

Uniwersytet Łódzki

monika.mularska@tlen.pl

\section{SUBJECTIVITY AND ORGANISATIONAL ACTIVITY OF ŁÓDŹ RESIDENTS}

\section{Summary}

The subject of this paper is subjectivity and social participation of Łódź residents in the context of civil society. Thus, the aim of the paper is to answer the question about the level of subjectivity of Łódź residents. The other aim is to examine the influence of subjectivity on one of the dimensions of the activity, namely, involvement in a more or less formalised non-government organisations.

${ }^{31}$ Komunikat CBOS, Spoteczeństwo obywatelskie 1998-2004, Warszawa 2004, s. 3.

${ }^{32}$ L. Juroszek, op. cit., s. 54. 